\title{
Salvação líquida: a questão soteriológica no protestantismo brasileiro de missão
}

\author{
Orientadora: Maria Clara Lucchetti Bingemer \\ Mestrando: Marcio de Carvalho Leal \\ Área de Concentração: Teologia Sistemático-Pastoral
}

Linha de Pesquisa: Fé e Cultura

Esta pesquisa centra-se no estudo da soteriologia tradicional ensinada pelo protestantismo brasileiro de missão. Busca-se desenvolver o tema a partir da percepção dualista presente nesta soteriologia, bem como a concepção a-histórica da mesma e apresenta como contraponto a teologia Moltmanniana. O trabalho se desenvolve em três capítulos que buscam estruturar esta dissertação: No primeiro, descreve-se a pós-modernidade na visão de Zygmunt Bauman e a herança teológica herdada pelo protestantismo brasileiro de missão; no segundo, desenvolve-se a observação da crise de modelo soteriológico dualista presente na teologia tradicional protestante e no terceiro, a apresentação da teologia Moltmanniana na prática de um seguimento de Cristo e da Missão Integral, propondo uma visão que envolva o ser humano em sua integralidade.

Palavras-chave: Pós-modernidade; protestantismo brasileiro de missão. 